Article

\title{
The integration of stock exchanges: The case of the Latin American Integrated Market (MILA) and its impact on ownership and internationalization status in Colombian brokerage firms
}

\author{
Beatriz Yepes-Rios*, Kelly Gonzalez-Tapia, Maria Alejandra Gonzalez-Perez \\ Universidad EAFIT, Colombia
}

\section{A R T I C L E I N F O}

\section{Article history:}

Received 1 November 2014

Accepted 31 July 2015

\section{JEL classification:}

G15

G24

F15

Keywords:

Integration

Stock exchanges

Brokerage firms

Capital markets

Latin American Integrated Market

\begin{abstract}
A B S T R A C T
This paper describes the changes in ownership and internationalization of the brokerage firms in Colombia as a result of the regional integration process of its stock exchange market through the Latin American Integrated Market (MILA). It proposes that the integration of stock exchanges generated transformations within the brokerage sector, and affected companies in response pursue different strategies to remain competitive in the current state of affairs. In the case of Colombia, stock exchange integration through MILA has resulted into mergers between local brokerage firms, acquisitions from both national and international companies and changes in ownership.
\end{abstract}

(c) 2015 Universidad ESAN. Published by Elsevier España, S.L.U. This is an open access article under the CC BY-NC-ND license (http://creativecommons.org/licenses/by-nc-nd/4.0/).

\section{Códigos JEL:}

G15

G24

F15

Palabras clave:

Integración

Bolsas de valores

Compañías de corretaje

Mercados de capital

Mercado Integrado Latinoamericano

\section{Integración de las bolsas de valores: el caso del Mercado Integrado Latinoamericano y su impacto sobre el estatus de titularidad e internacionalización de las compañías de corretaje colombianas}

\section{R E S U M E N}

Este artículo describe los cambios de titularidad y la internacionalización de las compañías de corretaje colombianas, como resultado del proceso de integración regional de su mercado bolsista, a través del Mercado Integrado Latinoamericano (MILA). El documento propone que la integración de las bolsas ha generado transformaciones dentro del sector de los corretajes y que, en respuesta, las empresas afectadas persiguen diferentes estrategias para seguir siendo competitivas dentro de la situación actual de los negocios. En el caso de Colombia, la integración de la bolsa a través del MILA ha originado fusiones entre los corretajes locales, adquisiciones por parte de empresas nacionales e internacionales y cambios de titularidad.

(C) 2015 Universidad ESAN. Publicado por Elsevier España, S.L.U. Este es un artículo Open Access bajo la licencia CC BY-NC-ND (http://creativecommons.org/licenses/by-nc-nd/4.0/).

\footnotetext{
* Corresponding author.

E-mail address: byepesri@eafit.edu.co (B. Yepes-Rios).
} 


\section{Introduction}

The recent intensification of movement of goods and services, financial capital, and knowledge around the world has increased economic interdependence between countries (Hitt, Ireland \& Hoskisson, 2012). This is proven by the fact that currently there are 258 regional trade agreements in place (World Trade Organization, 2014) accounting for more than half of international trade (OECD, 2014).

As an answer to this interdependence, countries, sectors and even companies around the world have recognized the need to leave behind their traditional schemes of operation and immersing themselves on the global market by integrating its operations, by reaching out to its neighbors to create alliances that allow them to be more competitive in the international environment. As a result, agreements have been signed between developed countries - as is the case of the European Union and the Canada-United States Free Trade Agreement- developed and developing countries, such as the Euro-Maghreb Agreement and the NAFTA; and developing countries - APEC, Andean Community, CARICOM, SADC, and SACU- (Schiff, 2003), and more recently the Pacific Alliance (Gutiérrez-Viana et al., 2013). This is also a reality for the financial sector where stock exchanges and its various stakeholders have followed the trend of integrating to participate more competitively in foreign markets (Cornelius, 1994; De Smidt \& van Rietbergen, 2002; Robinson, 2006; Stoltenberg, George, Lacey \& Cuthbert, 2011).

In this context, it is important to understand (1) how the integration of stock exchanges through MILA has affected firm level variables, such as ownership structure and internationalization, within the brokerage firms of the countries involved; (2) what have been the motivations for changing those structures; and (3) what have been the benefits for the parties involved and the barriers they need to overcome, in order to make the Latin American Integrated Market - hereinafter MILA- a reality. This initiative aims to create the first cross border integration of equities markets in Latin America through the harmonization of regulations regarding capital markets trades, the custody of securities of the parties involved (Chile, Peru, Colombia) and the use of technological tools (MILA, 2010). Furthermore, taking into consideration that the worldwide trend of the sector is to react to integration through mergers and acquisitions as a way to internationalize, it is relevant to provide information on how this process has influenced the current situation of brokerage firms, regarding ownership and the internationalization strategies that these organizations may need to pursue in response to this integration. The research was conducted in Colombia; a country that has become one of the leading examples in Latin America for dynamic and growing economies, with a GDP growth rate of 3.6\% in 2012 (Global Insight Colombia, 2013) and of 5.1\% in 2013 (Revista Semana, 2013), Colombia, has also been a promoter of regional integration, enhancing initiatives such as the Pacific Alliance and MILA itself, and it offers the proper scenario for the study since the number of brokerage firms participating in MILA are 12, the same number present in Chile and overcoming Peru. Furthermore, this country is selected as the center of the analysis taking into consideration the access to qualitative information derived from contacts with personnel working within the sector, that may provide a vision relevant to answer the described problematic.

Consequently, this paper aims to answer the following question: what changes have occurred in Colombian brokerage firms in terms of ownership and internationalization status as a result of the integration process of the stock exchange markets of Colombia, Peru and Chile, through MILA?

In order to do so, this paper provides a theoretical and conceptual framework that supports the integration of stock exchange markets. This will be developed first by addressing and explaining the concepts of economic integration and regional agreements that may take the form of integration of stock exchanges. Then, information will be provided about MILA and Colombia's stock exchange as a member of this agreement. Finally, it describes the situation of brokerage firms in Colombia in terms of ownership and internationalization status as a result of MILA.

\subsection{Literature review}

Since its origins, both international divisions and international integration have marked world history; however, it was only after the Second World War that economic, social and environmental aspects were included in the international scenario (Buzan \& Little, 2002). From that point on, and considering the increased importance of economic issues, states started to develop alliances and agreements that contributed to the attainment of its objectives in terms of social and economic welfare (Whalley, 1998), through the creation of trade blocks, the elimination of trade barriers and the liberalization of the economy (Mirus \& Rylska, 2001).

Economic integration is analyzed in this review, from a theoretical perspective, using an evolutionary framework, in which several stages are stated taking into consideration the degree of the economic process (Balassa, 1974). These stages described several steps that start from the elimination of barriers to trade, called 'trade integration', passing through 'factor integration' understood as the liberalization in the movement of economic factors; 'policy integration' defined as the harmonization of economic policies and finally, a total unification of these economic policies, known as 'total integration' (Balassa, 1974).

Frequently, countries located in the same region or geographically concentrated engage in this type of integration with the objective of fostering regional trade and improving economic conditions of a particular region (Baldwin \& Venables, 1995). These agreements are called Regional Integration Agreements (RIAs) or Preferential Trading Arrangements, and look for the establishment of a "geographically discriminatory trade policy, which denotes a region with reduced tariffs" (Baldwin \& Venables, 1995).

RIAs bring some benefits for the signatory countries, which make these agreements attractive tools for states that want to enhance its international competitiveness (Mukhopadhyay, Thomassin \& Chakraborty, 2012). For instance, when pursuing commerce activities within a regional agreement, the signatory parties get internal advantages that exclude external parties, i.e. tariff reduction, free movement of capital, labor, and common investment policies, among others (Birdsall \& Lawrence, 1999; Baldwin \& Venables, 1995). The above, contributes to strengthen the region and allow countries to negotiate strategically as a block (Whalley, 1998). Additionally, RIAs are used by smaller nations to strengthen its negotiation power when conducting block discussions in order to get benefits in the final arrangements that otherwise would not have been achieved (Whalley, 1998).

Furthermore, this type of agreements creates a scenario to enhance further multilateral trade agreements, since the gains obtained from the treaty can highly influence the establishment of new multilateral agreements looking for economic and social improvements (Levy, 1997).

Another general benefit of these treaties is the promotion of trade around the world (Birdsall \& Lawrence, 1999). This can be evidenced, as previously stated, in the current existence of more than 200 Regional Agreements in force, (WTO, 2014) that account for more than half of international trade (OECD, 2014). As mentioned, RIAs promote international trade; however they can also create trade diversion by fostering international activities between signatory countries, which can sacrifice better trade opportunities with external parties (Newfarmer, 2006; Robertson \& Estevadeordal, 2009). 
Regional Agreements included different sectors of national economies. In the case of the financial sector this type of agreements are signed under a framework of financial integration which is understood as the process that a country's financial market undergoes in order to become closely linked with markets from other countries (Brouwer, 2005; Ho, 2009).

Through financial integration, financial institutions aim to eliminate barriers in order to operate and provide services by pursuing formal or de facto efforts, as has been the cases of the Investment of Nymex in Montreal stock exchange, the merger of NYSE and Euronext, acquisition of Nomura by Instinet, the merger of AMX with Sidney Futures exchange, among others (MILA, 2010). In the case of formal efforts, agreements are signed to eliminate the restrictions that the countries may have to conduct cross border financial operations and to foster the harmonization of regulations, rules and taxes. When the explicit agreement is not present, the facto integration occurs trough the execution of activities that link the domestic and foreign markets, such as the international trading of securities, the presence of internal banks in the domestic market and the participation of foreign institutions in the insurance and pension markets, among others (Ho, 2009; Interamerican Development Bank, 2002).

This type of integration is particularly seen within the financial sector in Stock Exchange Markets that currently, as other institutions in the economy, are facing the challenges of globalization (Di Noia, 1998) and need to respond to the needs of the various stakeholders. The latter were identified by Dorodnykh (2014) as the market operators, member and regulators, issuers, investors, technology providers and the infrastructure itself in terms of trading: clearing and settlement.

In accordance, stock exchanges that are controlled, selfregulated and governed by different types of members such as governments, are being replaced by integrated markets that in the broad sense, according to Dorodnykh (2014), it means that when fully integrated, all potential market participants equally characterized, face the same set of rules when dealing with financial instruments and/or services, have equal access those financial instruments and/or services, and are treated equally when they are active in the market. To make this possible, mergers and acquisitions, as attempts of cooperation, have become a valuable strategy to increase the value of stock exchanges and ensure competitiveness, efficiency and growth, which is the ultimate objective of these institutions (Cybo-Ottone and Murgia, 2000; Domowitz, 1995; Domowitz \& Steil, 1999; Hasan \& Schmiedel, 2004; Kokkoris \& Olivares-Caminal, 2008 as quoted in Dorodnyk, 2014).

The most important factors that have motivated these changes in the structure of the stock exchanges and even in the framework in which they operate, are the advances in information and communication technologies, market deregulation or liberalization, the removal of statutory controls and increased competition (Di Noia, 1998; Dorodnykh, 2014; Mobarek, 2013; Raj \& Dhal, 2008). As well as the related benefits of the integration process, directly associated with increased competitiveness, transparency, a better flow of information, cost efficiency and accountability (Dorodnyk, 2014).

Stock exchange integration brings alongside its benefits some risks that must be taken into account, among them it is possible to highlight contagion, spillover effects and regional shocks. As well as the difficulties associated with the lack of adequate risk diversification that result from the financial linkages created throughout the process (Allen \& Gale, 2000; Claessens \& Forbes, 2004; Halac, Schmukler and Zoido-Lobatón, 2006; Lagunoff \& Schreft, 2001).

No matter what the associated risks are, stock exchange markets have experienced integration processes, mainly through mergers and acquisitions, during the last 15 years (Dorodnykh, 2013; Nielsson, 2009). Some of the most important ones are the following: in Europe, the creation of Euronext in 2000, where the exchanges of Amsterdam, Brussels and Paris merged (Nielsson, 2009); the London Stock Exchange and the Borsa Italiana merger in 2007 (London Stock Exchange, 2007); also, the creation of the CEE Group with the cooperation between Central and Eastern European stock exchanges (Schröder, 2001). In the case of North America, CME Group and the international acquisition of Euronext by the NYSE and NASDAQ integration with Nordic stock exchange operator OMX AB. (Dorodnykh, 2013). In Latin America stock exchanges integration processes are very recent and currently there is only one initiative, the MILA.

Under this scenario, it is important to define the main pillars of this agreement and to analyze how brokerage firms in Colombia have dealt with the challenges proposed by MILA.

As it has been developed in this section, there is a growing tendency of creating integration agreements worldwide that take into consideration not only trade of goods and services, but also financial issues. According to previous studies, these integration agreements redounds in the promotion of internationalization processes since they create the proper scenario (duty and other regulations, governmental promotion activities, lowering of taxes and improvement of investors conditions) for companies to internationalize (Cornelius, 1994; Tambi, 2005). At the same time, internationalization creates several effects at the firm level, such as the improvement in the productivity, development of new skills, acquirement of new technologies and new knowledge, and changes in infrastructure and organizational structure (Wakasugi et al., 2008). These changes are related to the necessity to adapt to new markets, different conditions, and to respond successfully to the challenges posted by internationalization. Due to that, it is possible to expect that brokerage firms in Colombia suffered some firm level changes in response to the creation of MILA.

Although, there are several cases of financial integration in the different continents, in Latin America the tendency has begun with the integration of Peru's, Chile's and Colombia's stock exchange markets, through an initiative called Latin American Integrated Market. This paper will contribute to create a source of information about MILA and how this integration agreement has generated changes at the firm level, in terms of ownership and internationalization status, in Colombian brokerage firms. Since the topic is new, it aims to set a precedent on this integration agreement and on the possible consequences it has brought to brokerage firms in Colombia.

\subsection{Methodology}

In order to analyze the implications of the integration of stock exchange markets, more specifically the MILA, and its consequences on Colombian brokerage sector, particularly for Colombian firms, this paper uses a descriptive-research approach. A descriptive research approach attempts to develop a conceptual structure, based on previous studies, to form ideas about the examined phenomena and therefore provide answers to the formulated question (Kumar, 1999). To do so, a research based on publicly available secondary sources -databases, books, magazines and journals- has been conducted.

Although, documentary research is not experimental and therefore, can be considered to be subjective when providing effective results, it has proved to be an important and useful methodology in social studies because it allows the enhancement of knowledge of situations that need a historical and sociocultural contextualization by increasing the comprehension of social phenomena (Sa-Silva, De Almeida \& Guindani, 2009). This type of study will contribute to theory by creating knowledge based on previous literature and by enriching the theoretical background needed to explain situations related to the analyzed topic (Higson-Smith et al., 2000). 
A case study methodology was used as well to develop the current research, since the particular study of the situation of brokerage firms in Colombia will provide deep information of the analyzed companies (Eisenhardt, 1989). Case study research is used to investigate a "contemporary phenomena within its real life context, especially when the boundaries between phenomenon and context are not clear evident" (Yin, 1994); therefore, this methodology is appropriate for the present inquiry. The case of brokerage firms in Colombia, within the MILA framework was built and analyzed, using theoretical information from journals, magazines and texts books, aiming to get the required information to determine the impact that stock market integration (through the MILA) has had in ownership and internationalization status of these companies, this information was contrasted with data acquired through interviews with personnel from the active brokerage firms as well as the legal documentation of each company, publicly available in the Superintenedencia Financiera de Colombia and in the web pages of the companies under study.

This particular study focuses on 24 active brokerage firms in Colombia and the changes they have faced in ownership and internationalization status since 2009 to the first quarter of 2014. This time framework was chosen in this paper because although the MILA agreement was implemented in 2010, the first intention for integration has its origins in September 2008, which could have started to generate transformations in brokerage firms starting in 2009.

The trend of economic integration is generating, worldwide, the establishment of agreements and alliances that according to some studies enhances internationalization and creates welfare to the society (Frankel \& Romer, 1999; Keller \& Yeaple, 2003; Whalley, 1998; Young, 1991). In this context, countries have pursued liberalization of policies opening their economies and eliminating barriers to trade (Dollar \& Kraay, 2001).

Colombia has not been an exception to this tendency. It opened its economy in the 1990s embracing since then globalization with its associated risks and benefits and creating new environmental conditions that allowed Colombian companies to relate with international organizations (Edwards \& Steiner, 2000; Sebastian, 2001).

As a consequence, this country substituted its closed markets with an active participation in internationalization processes which can be evidenced in the number of trade agreements that the country has signed and the important role it acquired in multilateral forums. Currently, Colombia has different commercial and investment agreements with Mexico, El Salvador, Guatemala, Honduras, Chile, EFTA, Canada, USA, Venezuela, Nicaragua and the European Union. And it also participates in multilateral organizations such as the Andean Community, CARICOM, MERCOSUR and the Pacific Alliance. This country is also creating new trade initiatives with countries as South Korea, Costa Rica, and Israel (MinCIT, 2014).

In the financial sector the trend can also be identified, particularly in the case of the capital markets whose evolution was interlinked with the economic development of the country and the industrialization process derived from the "Coffee Boom" - Bonanza Cafetera- at the beginning of the twentieth century. These processes generated the mobilization of capitals and created between entrepreneurs the need to accumulate capital mainly to create new companies or to invest in order to further promote the country‘s development (Ministerio de Hacienda y Crédito Público de Colombia $^{1}$, 2008). As a result, local companies began to operate in the national capital market by offering citizens the opportunity to trade Colombian stocks and bonds, making investment a very

\footnotetext{
1 In English Ministry of Treasury and Public Credit.
}

important economic activity. As the business evolved the need to create an institution that controlled and promoted the fair and well function of the market led to the creation of the Bolsa de Bogotá ${ }^{2}$ in 1928, the Bolsa de Medellín ${ }^{3}$ in 1961 and the Bolsa de Occidente ${ }^{4}$ in Cali, in 1983 (Ministerio de Hacienda y Crédito Público de Colombia, 2008). This was the first stepping-stone for the creation of an organized system in Colombia and gradually, these initiatives led to the creation of the "Bolsa de Valores de Colombia (BVC)" in 2001. This institution facilitated the exchange of information, improved transactions and consolidated the capital markets locally.

\section{Findings}

With the transformation of the world and of the Colombian economy, the challenge for the stock exchange market in this country grew in response to international competition. This requires changes in order to comply with the needs of the different stakeholders of capital markets that in the case of financial institutions and investors are economies of scale and scope (Carretta \& Nicolini, 2006; McAndrews \& Stefanadis, 2002). For the intermediaries and issuers, the change is higher transparency and efficiency and cost cutting by avoiding the duplicated cost related to the market infrastructure (Pagano \& Padilla, 2005; Varadi \& Boppana, 2009). And for investors is the availability of a more diversified portfolio and higher market liquidity (Floreani \& Polato, 2010).

In consequence, integration became an important tool to achieve this development due to the lack of the needed level of specialization, tradability and transparency of information among other characteristics that would allow the Colombian market to comply with these requirements. In this context, Colombia, Peru and Chile, started to work on an alliance between the Bolsa de Valores de Colombia, the Bolsa de Valores de Lima and the Bolsa de Comercio de Santiago for the unification and expansion of the existent markets and the diversification of associated risk. This initiative called Mercado Integrado Latinoamericano (MILA), seeks to create a regional actor able to compete with Mexico's and Brazil's stock exchanges without organizational or operational integration, but instead through the use of technological tools and the harmonization of the legislation and regulation regarding negotiation in capital markets and assets custody, that allows the free trade of equities by order routing between brokerage firms in each country, towards the origin markets, without losing their independence and regulatory autonomy; promoting the possibility to grow as integrated markets. This began to operate on May 30th, 2011, (MILA, 2014) and has given the opportunity for each country to further strengthen their position in the continent.

The origins of MILA are found in the "intention agreement" that took place in September 2008. In this agreement, Peru, Colombia and Chile stated the objective of developing a feasibility study for the project and define a unique equity integration model that was going to be managed by each participant. Initially, the model was divided into two stages: the first stage, implemented in 2010 , included points such as the authorization for the local negotiation of foreign securities and the possibility of operating in the secondary market, the second phase took place between 2011 and 2012 , and allowed intermediaries to operate directly in the markets and extended the scope of negotiations to fixed income securities and derivatives.

To achieve the above and consolidate this integration, MILA has experienced throughout time several difficulties and challenges, which were mainly related to the regulatory framework of each

\footnotetext{
2 In English Bogota's Stock Exchange.

3 In English Medellin's Stock Exchange.

4 In English West Stock Exchange.
} 
Table 1

Issuers by sector and country within MILA.

\begin{tabular}{|c|c|c|c|c|c|c|c|c|}
\hline \multirow[t]{2}{*}{ Sector } & \multicolumn{2}{|c|}{ Chile } & \multicolumn{2}{|c|}{ Colombia } & \multicolumn{2}{|c|}{ Peru } & \multicolumn{2}{|c|}{ Total } \\
\hline & No. of companies & \%Sector & No. of companies & \%Sector & No. of companies & \%Sector & Total & Total \% \\
\hline Agricultural & 8 & $4 \%$ & 0 & $0 \%$ & 21 & $8 \%$ & 29 & $5 \%$ \\
\hline Food and beverages & 17 & $8 \%$ & 0 & $0 \%$ & 0 & $0 \%$ & 17 & $3 \%$ \\
\hline Commercial & 14 & $7 \%$ & 1 & $1 \%$ & 0 & $0 \%$ & 15 & $3 \%$ \\
\hline Diverse & 28 & $14 \%$ & 0 & $0 \%$ & 67 & $24 \%$ & 95 & $17 \%$ \\
\hline Finance & 63 & $31 \%$ & 14 & $17 \%$ & 42 & $15 \%$ & 119 & $21 \%$ \\
\hline Industrial & 11 & $5 \%$ & 60 & $73 \%$ & 55 & $20 \%$ & 126 & $23 \%$ \\
\hline Mining & 6 & $3 \%$ & 0 & $0 \%$ & 45 & $16 \%$ & 51 & $9 \%$ \\
\hline Services & 18 & $9 \%$ & 6 & $7 \%$ & 14 & $5 \%$ & 38 & $7 \%$ \\
\hline Public services & 36 & $18 \%$ & 1 & $1 \%$ & 30 & $11 \%$ & 67 & $12 \%$ \\
\hline Total & 201 & & 82 & & 274 & & 557 & \\
\hline
\end{tabular}

Own construction from MILA web page, 2014.

country. First, the involved parties had accounting registration models that differ greatly. Second, there were multiple restrictions for the operation of institutional investors. Third, the tax framework across countries did not favor the integration process. Lastly, the coordination to pursue the necessary changes within the states was very slow. However, the countries have actively participated in the creation of the adequate conditions to foster the integration, giving training to the involved institutions and changing the required structures to move forward with the stock market integration (MILA, 2010).

MILA works under general premises that need to be taken into consideration by the interested parties within the market. It is important to understand that the agreements are developed by the stock exchanges and the central repository of values from each country, not by companies themselves. However, organizations will have access to foreign markets locally using an automatized order routing model called DMA, registering the conducted businesses through a local intermediary. The negotiation must be done under the rules of the origin country of the securities but they are settled in the local currency of the country where the operation is executed.

In order to ensure the transparency of the information, all relevant facts must be available and clear for all the participants of the market simultaneously, which will avoid a possible distortion in the businesses. Local authorities will be responsible for supervision in each country and the tax treatment for the operations will remain as it is for the involved parties.

Nowadays, MILA has achieved its main objectives and it occupies the first position in Latin America, regarding the number of issuers (557, followed by Mexico 421 and Brazil 375). MILA also has the second largest stock market capitalization value and ranks third with respect to the negotiated volume in the region. Additionally, it has brought benefits to investors, issuers and intermediaries, who now have more alternatives to invest, more possibilities of diversifying the risk, a best risk-return balance and the possibility of creating new portfolios to distribute them to local clients (MILA, 2014).

In this scenario, it is important to highlight that Peru accounts with the largest number of issuers: two hundred and seventy four (274) listed companies, followed by Chile with two hundred and one (201) and Colombia with eighty two (82) organizations. These issuers are concentrated mainly in the financial and industrial sector (Table 1 will provide more information). In Chile, the most representative issuers participating in MILA are Ripley, LAN, Endesa, Falabella, Cencosalud and Concha y Toro. In Peru, important companies such as BCP, Intergroup, Socotiabank and Cerro Verde belong to MILA and in Colombia, Ecopetrol, Bancolombia, Argos, Isagen and BVC are the most recognized organizations involved in the process.

Regarding intermediaries, that for this specific case area the brokerage firms, Chile has the broader selection with thirty (30) companies providing these services, while Colombia has twenty-four (24) and Peru twenty-three (23). For a total of seventyeight (78) brokerage firms participating in this integrated market.

For these companies in the Colombian brokerage sector, MILA has broadened the international perspective to a stronger interchange and unification of market and businesses. This has not only attracted international firms like Larrain Vial from Chile, which started operations in the Colombian brokerage sector in 2013 (Larrain, 2014) but has also redefined the ownership and international status of some of them, mainly through mergers and acquisitions, as can be observed in Table 2, located at the end of this section.

Even when most of the twenty four (24), active brokerage firms registered in the Sistema Integral de Información del Mercado de Valores $^{5}$-SIMEV, are local independent players, where the equity and the ownership of the majority of the available resources managed, belong to individual investors (owners) (Superintendencia Financiera de Colombia, 2014); some firms, have underwent merger and acquisitions within MILA framework with national and international companies.

Currently and in MILA context -since 2009, with the intention agreement- there have been four (4) acquisitions from international players, as follows: Banco Santander Colombia and its brokerage firm Santander Investment Valores, which was acquired by Corpbanca from Chile; Correval, a company that currently has $49 \%$ of Colombian ownership and 51\% ownership from Credicorp, a Peruvian company; Bolsa y Renta, acquired by the Brazilian investment bank, BTG Pactual; and RBS Securities Colombia S.A, which was bought by and United States bank, ScotiaBank (Superintendencia Financiera de Colombia, 2012; Díaz, 2013). Two (2) acquisitions and one (1) merger with national companies: the merger between Casa de Bolsa Corficolombiana SA, Valores del Popular SA and Valores Bogotá SA that was acquired by Valores de Occidente Sociedad Comisionista de Bolsa SA in 2009 (Superintendencia Financiera de Colombia, 2012); Corredores Asociados acquired by Davivienda a Colombian commercial bank (El Espectador, 2013a,b), both in 2013; and SumaValores that merged with Nacional de Valores SA in 2010. This means that $29.2 \%$ of brokerage firms in Colombia have faced ownership transformations within the MILA context; $57.1 \%$ of these transformations took place with international organizations and $42.9 \%$ with national companies. It is important to highlight that $85.7 \%$ of the ownership transformation was done through acquisitions and $14.3 \%$ by a merger

In this context, mergers and acquisitions, as a current phenomenon within the financial sector have appear as a result of the consolidation occurring in the sector since the 1980 , explained mainly by the financial and technological innovation,

\footnotetext{
5 In English, Information System of the stock exchange market.
} 
Table 2

Changes in Colombian brokerage firms within MILA context.

\begin{tabular}{|c|c|c|c|c|c|c|c|c|c|}
\hline Brokerage firm & Type of change & Partner & Type of partner & $\begin{array}{l}\text { Origin of } \\
\text { partner }\end{array}$ & $\begin{array}{l}\text { Year of the } \\
\text { change }\end{array}$ & Previous name & New name & Part of a Bank & $\begin{array}{l}\text { Year as part of } \\
\text { a Bank }\end{array}$ \\
\hline $\begin{array}{l}\text { ACCIONES Y VALORES SA } \\
\text { COMISIONISTAS DE BOLSA }\end{array}$ & $\mathrm{N} / \mathrm{A}$ & $\mathrm{N} / \mathrm{A}$ & $\mathrm{N} / \mathrm{A}$ & $\mathrm{N} / \mathrm{A}$ & $\mathrm{N} / \mathrm{A}$ & $\mathrm{N} / \mathrm{A}$ & $\mathrm{N} / \mathrm{A}$ & No & $\mathrm{N} / \mathrm{A}$ \\
\hline AFIN SA COMISIONISTA DE BOLSA & $\mathrm{N} / \mathrm{A}$ & $\mathrm{N} / \mathrm{A}$ & N/A & $\mathrm{N} / \mathrm{A}$ & $\mathrm{N} / \mathrm{A}$ & $\mathrm{N} / \mathrm{A}$ & N/A & No & $\mathrm{N} / \mathrm{A}$ \\
\hline $\begin{array}{l}\text { ALIANZA VALORES COMISIONISTA } \\
\text { DE BOLSA SA }\end{array}$ & $\mathrm{N} / \mathrm{A}$ & $\mathrm{N} / \mathrm{A}$ & $\mathrm{N} / \mathrm{A}$ & $\mathrm{N} / \mathrm{A}$ & $\mathrm{N} / \mathrm{A}$ & N/A & N/A & No & $\mathrm{N} / \mathrm{A}$ \\
\hline $\begin{array}{l}\text { ASESORES EN VALORES SA } \\
\text { COMISIONISTAS DE BOLSA }\end{array}$ & $\mathrm{N} / \mathrm{A}$ & $\mathrm{N} / \mathrm{A}$ & $\mathrm{N} / \mathrm{A}$ & $\mathrm{N} / \mathrm{A}$ & $\mathrm{N} / \mathrm{A}$ & $\mathrm{N} / \mathrm{A}$ & $\mathrm{N} / \mathrm{A}$ & No & $\mathrm{N} / \mathrm{A}$ \\
\hline ASESORÍAS E INVERSIONES SA & N/A & N/A & $\mathrm{N} / \mathrm{A}$ & $\mathrm{N} / \mathrm{A}$ & $\mathrm{N} / \mathrm{A}$ & N/A & $\mathrm{N} / \mathrm{A}$ & No & N/A \\
\hline $\begin{array}{l}\text { BBVA VALORES COLOMBIA SA } \\
\text { COMISIONISTA DE BOLSA - BBVA } \\
\text { VALORES }\end{array}$ & $\mathrm{N} / \mathrm{A}$ & $\mathrm{N} / \mathrm{A}$ & $\mathrm{N} / \mathrm{A}$ & $\mathrm{N} / \mathrm{A}$ & $\mathrm{N} / \mathrm{A}$ & $\mathrm{N} / \mathrm{A}$ & $\mathrm{N} / \mathrm{A}$ & Yes & 1990 \\
\hline $\begin{array}{l}\text { BTG PACTUAL SA COMISIONISTA } \\
\text { DE BOLSA }\end{array}$ & Acquisition & BTG Pactual & $\begin{array}{l}\text { Investment } \\
\text { Bank }\end{array}$ & Brazil & 2012 & $\begin{array}{l}\text { 1968: Luis } \\
\text { Carlos Vargas } \\
\text { Molina y Cía } \\
\text { 1992: Bolsa y } \\
\text { Renta SA } \\
\text { Comisionista } \\
\text { de Bolsa }\end{array}$ & $\begin{array}{l}\text { BTG Pactual SA } \\
\text { Comisionista } \\
\text { de Bolsa }\end{array}$ & Yes & 2012 \\
\hline $\begin{array}{l}\text { CASA DE BOLSA SA SOCIEDAD } \\
\text { COMISIONISTA DE BOLSA named } \\
\text { before Valores de Occidente } \\
\text { Sociedad Comisionista de Bolsa } \\
\text { SA }\end{array}$ & $\begin{array}{l}\text { Merger by } \\
\text { Acquisition }\end{array}$ & $\begin{array}{l}\text { Merger between } \\
\text { Casa de Bolsa } \\
\text { Corficolombiana } \\
\text { SA, Valores del } \\
\text { Popular SA and } \\
\text { Valores Bogotá SA } \\
\text { and acquired by } \\
\text { Valores de } \\
\text { Occidente Sociedad } \\
\text { Comisionista de } \\
\text { Bolsa S.A }\end{array}$ & Brokerage firm & Colombia & 2009 & $\begin{array}{l}\text { Valores de } \\
\text { Occidente } \\
\text { Sociedad } \\
\text { Comisionista } \\
\text { de Bolsa SA }\end{array}$ & $\begin{array}{l}\text { Casa de Bolsa } \\
\text { SA Sociedad } \\
\text { Comisionista } \\
\text { de Bolsa }\end{array}$ & Yes & 2009 \\
\hline $\begin{array}{l}\text { CITIVALORES SA COMISIONISTA DE } \\
\text { BOLSA }\end{array}$ & $\mathrm{N} / \mathrm{A}$ & $\mathrm{N} / \mathrm{A}$ & $\mathrm{N} / \mathrm{A}$ & $\mathrm{N} / \mathrm{A}$ & $\mathrm{N} / \mathrm{A}$ & $\mathrm{N} / \mathrm{A}$ & $\mathrm{N} / \mathrm{A}$ & Yes & 1993 \\
\hline $\begin{array}{l}\text { COMPASS GROUP SA } \\
\text { COMISIONISTA DE BOLSA named } \\
\text { before Promotora Bursátil de } \\
\text { Colombia }\end{array}$ & Acquisition & $\begin{array}{l}\text { Compass Group } \\
\text { Holding } \\
\text { Ltda.-Compass } \\
\text { Group LLC }\end{array}$ & $\begin{array}{l}\text { Investment } \\
\text { Advisor }\end{array}$ & United States & 2008 & $\begin{array}{l}\text { Promotora } \\
\text { Bursátil de } \\
\text { Colombia }\end{array}$ & $\begin{array}{l}\text { Compass } \\
\text { Group SA } \\
\text { Comisionista } \\
\text { de Bolsa }\end{array}$ & No & $\mathrm{N} / \mathrm{A}$ \\
\hline $\begin{array}{l}\text { COMPAÑÍA DE PROFESIONALES DE } \\
\text { BOLSA SA }\end{array}$ & $\mathrm{N} / \mathrm{A}$ & $\mathrm{N} / \mathrm{A}$ & $\mathrm{N} / \mathrm{A}$ & $\mathrm{N} / \mathrm{A}$ & $\mathrm{N} / \mathrm{A}$ & $\mathrm{N} / \mathrm{A}$ & $\mathrm{N} / \mathrm{A}$ & No & $\mathrm{N} / \mathrm{A}$ \\
\hline $\begin{array}{l}\text { CORPBANCA INVESTMENT } \\
\text { VALORES COLOMBIA SA } \\
\text { COMISIONISTA DE BOLSA }\end{array}$ & Acquisition & $\begin{array}{l}\text { Acquisition linked } \\
\text { with the } \\
\text { acquisition of the } \\
\text { bank explaines in } \\
\text { observations by } \\
\text { Corpbanca }\end{array}$ & Bank & Chile & 2012 & $\begin{array}{l}\text { Santander } \\
\text { Investment } \\
\text { Valores } \\
\text { Colombia S.A } \\
\text { Comisionista } \\
\text { de Bolsa }\end{array}$ & $\begin{array}{l}\text { Corpbanca } \\
\text { Investment } \\
\text { Valores } \\
\text { Colombia S.A } \\
\text { Comisionista } \\
\text { de Bolsa }\end{array}$ & Yes & 1997 \\
\hline $\begin{array}{l}\text { CORREDORES ASOCIADOS SA } \\
\text { COMISIONISTA DE BOLSA }\end{array}$ & Acquisition & Banco Davivienda & $\begin{array}{l}\text { Commercial } \\
\text { Bank }\end{array}$ & Colombia & 2013 & $\mathrm{~N} / \mathrm{A}$ & $\mathrm{N} / \mathrm{A}$ & Yes & 2013 \\
\hline CREDICORP CAPITAL COLOMBIA SA & Acquisition & $\begin{array}{l}\text { Credicorp Capital - } \\
\text { Banco de Crédito } \\
\text { del Perú (BCP) }\end{array}$ & $\begin{array}{l}\text { Commercial } \\
\text { Bank }\end{array}$ & Peru & 2011 & Correval & $\begin{array}{l}\text { Credicorp } \\
\text { Capital } \\
\text { Colombia S.A }\end{array}$ & Yes & 2011 \\
\hline
\end{tabular}




\begin{tabular}{|c|c|c|c|c|c|c|c|c|c|}
\hline Brokerage firm & Type of change & Partner & Type of partner & $\begin{array}{l}\text { Origin of } \\
\text { partner }\end{array}$ & $\begin{array}{l}\text { Year of the } \\
\text { change }\end{array}$ & Previous name & New name & Part of a Bank & $\begin{array}{l}\text { Year as part of } \\
\text { a Bank }\end{array}$ \\
\hline $\begin{array}{l}\text { DAVIVALORES SACOMISIONISTA } \\
\text { DE BOLSA }\end{array}$ & Merger & Grupo Bolivar & $\begin{array}{l}\text { Investment } \\
\text { Society }\end{array}$ & Colombia & 1992 & $\begin{array}{l}\text { 1974: Corredor } \\
\text { y Cárdenas SC } \\
\text { 1985 Corredor } \\
\text { y Alban SC } \\
\text { 1986: Corredor } \\
\text { y Alvan S.A } \\
\text { 1989: Corredor } \\
\text { y Alvna S.S } \\
\text { Comisionistas } \\
\text { de Bolsa }\end{array}$ & $\begin{array}{l}\text { Davivalores S.A } \\
\text { Comisionista } \\
\text { de Bolsa }\end{array}$ & Yes & 1992 \\
\hline $\begin{array}{l}\text { GLOBAL SECURITIES SA } \\
\text { COMISIONISTA DE BOLSA }\end{array}$ & Acquisition & $\begin{array}{l}\text { The Global } \\
\text { Securities Group }\end{array}$ & $\begin{array}{l}\text { Financial } \\
\text { Group }\end{array}$ & United States & 2006 & $\begin{array}{l}\text { 1993: } \\
\text { Compañía } \\
\text { Integral de } \\
\text { Valores S.A } \\
\text { 1988: } \\
\text { Pichincha } \\
\text { Valores S A } \\
\text { Comisionista } \\
\text { de Bolsa }\end{array}$ & $\begin{array}{l}\text { Global } \\
\text { Securities SA } \\
\text { Comisionista } \\
\text { de Bolsa }\end{array}$ & No & $\mathrm{N} / \mathrm{A}$ \\
\hline HELM COMISIONISTA DE BOLSA SA & $\mathrm{N} / \mathrm{A}$ & $\mathrm{N} / \mathrm{A}$ & $\mathrm{N} / \mathrm{A}$ & N/A & $\mathrm{N} / \mathrm{A}$ & $\mathrm{N} / \mathrm{A}$ & $\mathrm{N} / \mathrm{A}$ & Yes & 1981 \\
\hline $\begin{array}{l}\text { LARRAIN VIAL COLOMBIA SA } \\
\text { COMISIONISTA DE BOLSA }\end{array}$ & $\begin{array}{l}\text { Greenfield } \\
\text { Investment } \\
\text { from a Chilean } \\
\text { Company in } \\
\text { Colombia }\end{array}$ & $\mathrm{N} / \mathrm{A}$ & $\mathrm{N} / \mathrm{A}$ & $\mathrm{N} / \mathrm{A}$ & 2012 & $\mathrm{~N} / \mathrm{A}$ & $\mathrm{N} / \mathrm{A}$ & No & $\mathrm{N} / \mathrm{A}$ \\
\hline $\begin{array}{l}\text { OLD MUTUAL SKANDIA VALORES } \\
\text { SA SOCIEDAD COMISIONISTA DE } \\
\text { BOLSA }\end{array}$ & Acquisition & Old Mutual Group & $\begin{array}{l}\text { International } \\
\text { Financial } \\
\text { Services Group }\end{array}$ & South Africa & 2006 & $\begin{array}{l}\text { Skandia } \\
\text { Valores S.A } \\
\text { Sociedad } \\
\text { Comisionista } \\
\text { de Bolsa }\end{array}$ & $\begin{array}{l}\text { Old Mutual } \\
\text { Skandia } \\
\text { Valores SA } \\
\text { Sociedad } \\
\text { Comisionista } \\
\text { de Bolsa }\end{array}$ & No & $\mathrm{N} / \mathrm{A}$ \\
\hline $\begin{array}{l}\text { SCOTIA SECURITIES (COLOMBIA) } \\
\text { SA SOCIEDAD COMISIONISTA DE } \\
\text { BOLSA }\end{array}$ & Acquisition & ScotiaBank & Bank & United States & 2010 & $\begin{array}{l}\text { 2004: RBS } \\
\text { Securities } \\
\text { Colombia SA } \\
\text { Sociedad } \\
\text { Comisionista } \\
\text { de Bolsa }\end{array}$ & $\begin{array}{l}\text { Scotia } \\
\text { Securities } \\
\text { (Colombia) SA } \\
\text { Sociedad } \\
\text { Comisionista } \\
\text { de Bolsa }\end{array}$ & Yes & 2010 \\
\hline $\begin{array}{l}\text { SERFINCO SA COMISIONISTA DE } \\
\text { BOLSA }\end{array}$ & $\mathrm{N} / \mathrm{A}$ & $\mathrm{N} / \mathrm{A}$ & $\mathrm{N} / \mathrm{A}$ & $\mathrm{N} / \mathrm{A}$ & $\mathrm{N} / \mathrm{A}$ & $\mathrm{N} / \mathrm{A}$ & $\mathrm{N} / \mathrm{A}$ & No & $\mathrm{N} / \mathrm{A}$ \\
\hline $\begin{array}{l}\text { SERVIVALORES GNB SUDAMERIS } \\
\text { SA COMISIONISTA DE BOLSA } \\
\text { (antes SumaValores) }\end{array}$ & $\begin{array}{l}\text { 1. Acquisition } \\
\text { 2. Merger }\end{array}$ & $\begin{array}{l}\text { 1. Banco GNB } \\
\text { Sudameris } 2 \text {. } \\
\text { Nacional de } \\
\text { Valores S.A }\end{array}$ & $\begin{array}{l}\text { 1. Bank } \\
\text { 2. Brokerage } \\
\text { Firm }\end{array}$ & $\begin{array}{l}\text { 1.Colombia } \\
\text { 2. Colombia }\end{array}$ & $\begin{array}{l}\text { 1. } 2008 \\
\text { 2. } 2010\end{array}$ & $\begin{array}{l}\text { SumaValores } \\
\text { SA }\end{array}$ & $\begin{array}{l}\text { Servivalores } \\
\text { GNB Sudameris } \\
\text { S.A } \\
\text { Comisionista } \\
\text { de Bolsa }\end{array}$ & Yes & 2008 \\
\hline $\begin{array}{l}\text { ULTRABURSATILES SA } \\
\text { COMISIONISTA DE BOLSA }\end{array}$ & $\mathrm{N} / \mathrm{A}$ & $\mathrm{N} / \mathrm{A}$ & $\mathrm{N} / \mathrm{A}$ & $\mathrm{N} / \mathrm{A}$ & $\mathrm{N} / \mathrm{A}$ & $\mathrm{N} / \mathrm{A}$ & $\mathrm{N} / \mathrm{A}$ & No & $\mathrm{N} / \mathrm{A}$ \\
\hline $\begin{array}{l}\text { VALORES BANCOLOMBIA SA } \\
\text { COMISIONISTA DE BOLSA (antes } \\
\text { Suvalor SA) }\end{array}$ & Merger & $\begin{array}{l}\text { Between } \\
\text { Suramericana de } \\
\text { Valores SA } \\
\text { (SUVALOR) and } \\
\text { Comisionista de } \\
\text { Colombia S.A. } \\
\text { COMICOL }\end{array}$ & $\begin{array}{l}\text { Suramericana } \\
\text { de Valores SA } \\
\text { (SUVALOR) } \\
\text { acquires the } \\
\text { totality of } \\
\text { Comicol }\end{array}$ & Colombia & 2005 & $\begin{array}{l}\text { Suramericana } \\
\text { de Valores S.A } \\
\text { (SUVALOR) }\end{array}$ & $\begin{array}{l}\text { Valores } \\
\text { Bancolombia } \\
\text { SA } \\
\text { Comisionista } \\
\text { de Bolsa }\end{array}$ & Yes & 2006 \\
\hline
\end{tabular}

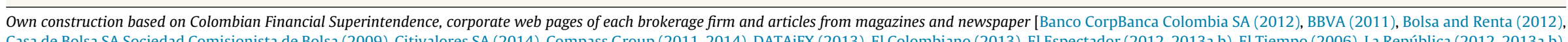

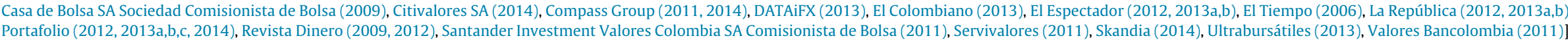


that redounded, recently, in the decline of the number of financial firms, and with changes in the surviving firm, that from that point and on are characterized by a larger size, diversification and operating in more places than never before (De Young, Evanoff, \& Molyneux, 2009).

According to literature, both mergers and acquisitions are seek by firms due to factors such as the improvement in efficiency that it generates and the enhancement in stockholder value as well as being considered a proper way to tackle the challenges and opportunities derived from the internationalization processes (De Young et al., 2009). However, according to De Young et al. (2009) currently there is no a consistent evidence of whether these processes benefit the participant financial firms, its costumers or if whether societal risks has increased or decreased as a consequence of the activity.

Regarding international status, 4 companies acquired international links, thorugh mergers and acquisitions that allow them to operate in international markets as single companies and offer Colombian consumers access to international products and markets (16.6\%): Bolsa y Renta, Banco Santander Colombia, Correval and RBS securities; these organizations were acquired by external parties and now operate as international players in Colombia. Consequently, $100 \%$ of international status changes in the status were done using acquisitions.

Another important fact observed in the sector, is that before the agreement $33 \%$ of the companies were owned by Banks, and the others remained family business; however within the MILA framework another $25 \%$ were acquired by banks, meaning that currently more than half of the firms no longer belong to families.

These transformations could be the beginning of a trend in the brokerage sector in the country, where firms will either merge in order to create bigger companies in terms of equity and financial solidity, or look for international investors which will become strategic partners, allowing them to leverage the costs, the technological infrastructure and to finance its activities (Díaz, 2013).

\section{Discussion}

The reviewed literature regarding economic integration, suggests that this type of financial integration generates changes in countries, industries and companies. The presence of signed or de facto regional agreements within the financial sector, particularly in stock exchanges brings benefits such as risk sharing, the promotion of economic growth and the improvement of capital allocation (Bodolus, 1974; Chinn \& Dooley, 1997; Cornelius, 1994; Darrat, Elkhal \& Hakim, 2000; Tambi, 2005), that have promoted the creation of integrated stock exchange markets around the world. This is a trend that the industry has experienced over the last 15 years (Dorodnykh, 2013). In this context, regional agreements that contribute to the unification of stock markets have influenced, as well, the behaviors and strategies of the various stakeholders of the financial market, where brokerage firms, as service and product providers, play a major role.

In Latin America this tendency, appears with the creation of MILA, the market integration project that attempts to merge the stock exchange markets of Chile, Peru and Colombia, providing the benefits of lowering transaction costs, improving cross border trade efficiencies and allowing investors to diversify their portfolios (Dorodnykh, 2014). This integration is said to have some impact on stakeholders of the sector, such as brokerage firms.

According to Cornelius (1994), one of these impacts is that international agreements that are developed in financial sectors promote financial integration and foster the internationalization of financial entities. For Colombia this is not a conclusive fact, since out of twenty-four listed (24) companies in the Colombian Financial Superintendence, four have pursued internationalization processes, this represents $16.66 \%$ of the total all of them through acquisitions with international partners within the 2008 MILA framework.

Another possible outcome of the integration of stock exchange markets is the transformation of the company's ownership (Dorodnykh, 2013) through strategic partnership within the country. This may allow the organization to increase is existing equity or leverage the requirements and costs needed to become a more competitive player, as shown by the case of the three companies acquired by national players, in Colombia, that represent a $12.5 \%$ of the total industry, and the processes where family or individual businesses have become part of a bank, such as the 6 companies seen in Table 2: Changes in Colombian brokerage firms within MILA context.

In general terms, literature showed that integration of stock exchange markets creates transformations for the companies of the sector. This seems to be the case in Colombia, were $29.16 \%$ of brokerage firms, have been immerse in changes in ownership and internationalization status, as a consequence of the integration of Colombia, Peru and Chile exchanges, either by mergers and acquisitions processes. However it is too early to conclude that this is the direct result of MILA.

It is important to conduct further research, to determine if the brokerage sector in Colombia has undertaken internationalization processes due to the presence of integration of stock exchanges such as MILA or if this agreement just constitutes a framework that facilitates the whole process. Furthermore, it would be ideal to conduct comparative studies with companies in the same sector in the other MILA country members.

\section{Conclusion}

This paper presents a theoretical approach to economic, financial and stock market integration. Within this context it analyzes how economic integration has led to the development of regional agreements that promote and even facilitate the integration of financial markets and specifically of stock exchanges, and how these processes have developed in Latin America with consequences for brokerage firms. Through this inquiry, it is possible to assess the current situation of the brokerage firms in Colombia regarding ownership and internationalization status, as a result of the integration process of its stock exchange market through MILA. The research was conducted through the use of secondary information in order to construct a theoretical background.

It is possible to conclude that as literature suggests, stock exchange integration and in general economic integration, creates changes within the sectors involved as shown by MILA and its impact on the Colombian brokerage sector where some firms have been acquired by international partners as was the case of Santander Investment Valores, Correval, Bolsa y Renta, and RBS Securities Colombia SA; others by national partners, such as Casa de Bolsa and Corredores Asociados; and Servivalores and a merger that resulted in the creation of Servivalores GND Sudameris in 2010. This trend in the brokerage sector in Colombia will most likely continue since companies tend to pursue strategic alliances in order to remain competitive both in the domestic and the regional scenario.

\section{References}

Allen, F., \& Gale, D. (2000). Financial Contagion. Journal of Political Economy, 108(1), $1-33$.

Balassa, B.A. (1974). Types of economic integration (No. 185). International Bank for Reconstruction and Development. Retrieved from: http://213. 154.74.164/invenio/record/16421/files/bela.pdf.[Accessed on 31/10/2013].

Banco CorpBanca Colombia S.A. (2012) Notas a los estados financieros consolidados. Por los años terminados el 31 de diciembre de 2012 y 2011. Retrieved from: https://www.bancocorpbanca.com.co/portal/formas/1384/NOTAS\%20ESTADOS 
\%20FINANCIEROS\%20CONSOLIDADOS\%20DIC\%202012.pdf.[Accessed

on $12 / 02 / 2014$

BBVA (2011).;1; Estados financieros consolidados. Retrieved from: https://www.bbva.com.co/pdf/informeconsolidaddo2011.pdf.[Accessed on $12 / 02 / 2014]$.

Baldwin, R. E., \& Venables, A. J. (1995). Regional economic integration. Handbook of international economics, 3, 1597-1644.

Birdsall, N., \& Lawrence, R.Z. (1999). Deep integration and trade agreements. Inge Kaul/Isabelle Grunberg/Marc A. Stern (Hg.): Global Public Goods. International Cooperation in the 21st Century. Oxford/New York, 128-151.

Bodolus, C. T. (1974). The internationalization of the securities markets. The Business Lawyer, 107-111.

Bolsa y Renta (2012) Notas a los estados financieros al 31 de diciembre del 2012 y 2011. Retrieved from: http://www.btgpactual.com.co/images/ userfiles/files/formas/quienesSomos/Estados/Notas\%20a\%20los\%20estados/ 2012.pdf.[Accessed on 12/02/2014].

Brouwer, G. (2005). Monetary and financial integration in Asia: Empirical evidence and issues. Asia Economic Cooperation and Integration, Asia Development Bank, Manila, the Philippines, 269-293.

Buzan, B., \& Little, R. (2002). Ten international systems in world history: Remaking the study of international relations. Historical Sociology of International Relations, 200.

Casa de Bolsa SA Sociedad Comisionista de Bolsa (antes Valores de Occidente Sociedad Comisionista de Bolsa SA. (2009). Notas a los estados financieros 31 de diciembre de 2009 y 2008 Retrieved from: http:// www.casadebolsa.com.co/pls/portal/docs/PAGE/VALORES_DE_OCCIDENTE/ CONTENIDO_VALORES/ARCHIVOS_VALORES/PDF/Notas_EE_FFCdB09.pdf. [Accessed on 12/02/2014].

Carretta, A., \& Nicolini, G. (2006). Integration of the European securities markets and links among stock exchanges: A cross-listing, cross-membership and crosstrading analysis. Paper presentato al convegno "Coordination and cooperation across organisational boundaries", organizzato dall'Università Cattolica S. Cuore di Milano, 20-21

Chinn, M. D., \& Dooley, M. P. (1997). Asia Pacific capital markets: Integration and implications for economic activity. In Regionalism versus multilateral trade arrangements, NBER-EASE Volume 6. University of Chicago Press.

Citivalores SA. (2014). Código de buen gobierno. Retrieved from: https:// www.citibank.com.co/resources/pdf/cod_buen_gob_citivalores29092010.pdf. [Accessed on 12/02/2014].

Claessens, S. \& Forbes, K. (2004). International financial contagion: The theory, evidence and policy implications. Presented at "the IMF's role in emerging markets economies" conference organized by RBWC, DNB and WEF. Amsterdam, the Netherlands. Retrieved from http://web.mit.edu/ kjforbes/www/ Shorter\%20Articles/InternationalFinancialContagion-Theory\%26Evidence.pdf. [Accessed on 20/02/2014].

Compass Group (2011). Notas a los estados financieros 31 de diciembre de 2011 y 2010. Retrieved from: http://www.cgcompass.com/Colombia/pdf/ Notas\%20a\%20los\%20Estados\%20Financieros.pdf.[Accessed on 12/02/2014].

Compass Group (2014). Compass Group/Our Company. Retrieved from: http:// www.cgcompass.com/web/International/OurCompany.html.[Accessed on 12/02/2014].

Cornelius, P. K. (1994). The internationalization of emerging stock markets. Intereconomics, 29(3), 131-138.

Cybo-Ottone, A., \& Murgia, M. (2000). Mergers and shareholder wealth in European banking. Journal of Banking and Finance, 24, 831-859.

Darrat, A. F., Elkhal, K., \& Hakim, S. R. (2000). On the integration of emerging stock markets in the Middle East. Journal of Economic Development, 25(2), 119-130.

DATAiFX (2013). Correval oficializa cambio de nombre a Credicorp Capital Colombia. Retrieved from: http://ec2-75-101-161-210.compute-1. amazonaws.com/noticias/correval-oficializa-cambio-de-nombre-credicorpcapital-colombia.[Accessed on 12/02/2014].

De Smidt, M., \& van Rietbergen, T. (2002). Stock markets for sale: European Integration and the consolidation of stock exchanges. Tijdschrift Voor Economische En Sociale Geografie (Journal of Economic E' Social Geography), 93(2), 208.

De Young, R., Evanoff, D. D., \& Molyneux, P. (2009). Mergers and acquisitions of financial institutions: A review of the post-2000 lLiterature. Journal of Financial Services Research., 36(2-3), 87-110.

Di Noia, C. (1998). Competition and integration among stock exchanges in Europe: Network effects, implicit mergers and remote access. Working Paper 98-03.

Díaz, C. (2013).Comisionistas: antecedentes y perspectivas. Revista Dinero. Retrieved from: http://www.dinero.com/opinion/columnistas/articulo/comisionistasantecedentes-perspectivas/183029.[Accessed on 09/02/2014].

Dollar, D., \& Kraay, A. (2001). Trade, growth, and poverty. World Bank, Development Research Group, Macroeconomics and Growth.

Domowitz, I. (1995). Electronic derivatives exchanges: Implicit mergers, network externalities, and standardization. Quarterly Review of Economics and Finance, 35(1), 163-175

Domowitz, I., \& Steil, B. (1999). Automation, trading costs, and the structure of the securities trading industry. Brooking-Wharton Papers on Financial Services, 99, $33-92$

Dorodnykh, E. (2013). What drives stock exchange integration? International Journal of Economic Sciences and Applied Research, (2), 47-79.

Dorodnykh, E. (2014). Stock market integration: An international perspective. Palgrave MacMillan. http://dx.doi.org/10.1057/9781137381705

Edwards, S., \& Steiner, R. (2000). On the crisis hypothesis of economic reform: Colombia 1989-91. Cuadernos de economía, 37(112), 445-493.
Eisenhardt, K. M. (1989). Building theories from case study research. Academy of Management Review, 532-550.

El Colombiano (2013). Correval se fortalece con la marca Credicorp Capital. Retrieved from: http://www.elcolombiano.com/BancoConocimiento/ C/correval_se_fortalece_con_la_marca_credicorp_capital/correval_se_fortalece_ con_la_marca_credicorp_capital.asp.[Accessed on 12/02/2014].

El Espectador (2012). Bolsa de Valores de Colombia notificó la modificación de la antigua marca RBS. Securities cambia a Scotia Securities. Retrieved from: http://www.elespectador.com/impreso/negocios/articulo360041-rbs-securities-cambia-scotia-securities. [Accessed on 12/02/2014].

El Espectador (2013). Global Securities se fortalece. Retrieved from: http://www. elespectador.com/noticias/economia/articulo-418707-global-securities-sefortalece 12/02/2014].

El Espectador (2013). Tras largas negociaciones Davivienda se hizo a Corredores Asociados. Retrieved from: http://www.elespectador.com/noticias economia/articulo-407500-tras-largas-negociaciones-davivienda-se-hizocorredores-asociado.[Accessed on 09/02/2014].

El Tiempo (2006). Arranca ola de movidas entre firmas comisionistas de bolsa. Retrieved from: http://www.eltiempo.com/archivo/documento/MAM1901483.[Accessed on 12/02/2014].

Floreani, J., \& Polato, M. (2010). Consolidation and business strategies in the securities industry: How securities exchanges create value? Research in World Economy, 1(1), 28.

Frankel, J. A., \& Romer, D. (1999). Does trade cause growth? American Economic Review, 89, 379-399.

Gutiérrez-Viana, Santiago; Gonzalez-Perez, María Alejandra; Rodriguez-Rios, Juan David \& Gutiérrez Gómez, Laura (2013). Evaluación de la justificación económica y política de la Alianza del Pacífico. Proexport: Bogotá. Available online at: www.tlc.gov.co/descargar.php?id=68684

Hasan, I., \& Schmiedel, H.(2004). Networks and equity market integration: European evidence. International Review of Financial Analysis, 13(5), 601-619.

Higson-Smith, C., Parle, J., Lange L., \& Tothill, A. (2000). Writing your research proposal: A workbook for first time and inexperienced researchers in the social sciences and humanities. http://www.nrf.ac.za/yenza/zip/proposal.zip. Accessed on: April 2012.

Hitt, M.A., Ireland, R.D., \& Hoskisson, R.E. (2012). Strategic management cases: Competitiveness and Globalization. CengageBrain. com.

Ho, N. W. (2009). Financial integration: Concepts and impacts. Macao Monetary Research Bulletin, 10, 69-84

Global Insight. (2013). Country intelligence report: Colombia. Business Source Complete. 1-21. Retrieved from: ttp://ehis.ebscohost.com.ezproxy.eafit.edu.co/ ehost/pdfviewer/pdfviewer?sid=9ee45eff-4478-4c58-b3c9-515d39f78ac7\%40 sessionmgr13\&vid=4\&hid=105. [Accessed on: 29/05/2013]

Halac, M., Schmukler, S. L., Zoido-Lobatón, P., \& Halac. (2006). Financial globalization, crises and contagion. In A. Morales-Zumaquero (Ed.), Internationa Macroeconomics: Recent developments. (pp. 207-225). New York: Nova Sciences Publishers.

Interamerican Development Bank (2002). Chapter 5: Financial integration Retrieved from: http://www.iadb.org/res/publications/pubfiles/pubb-2002e 7384.pdf.[Accessed on 09/11/2013].

Keller, W., \& Yeaple, S.R. (2003). Multinational enterprises, international trade and productivity growth: firm-level evidence from the United States. National Bureau of Economic Research, No. w9504.

Kokkoris, I., \& Olivares-Caminal. (2008). Lessons from the recent stock exchange merger activity. Journal of Competition Law E' Economics, 3(4), 837-869.

Kumar, R. (1999). Research methodology: A step-by-step guide for beginners (2nd ed.) Singapore: Pearson Education.

La República (2012). Cambio de marcas de Helm, Hsbc, ING y Skandia moverá más de US\$15 millones. Retrieved from: http://www.larepublica. co/finanzas/cambio-de-marcas-de-helm-hsbc-ing-y-skandia-mover\%C3\%A1m\%C3\%A1s-de-us15-millones_23014.[Acccessed on 12/02/2014].

La República (2013). Bice y Scotiabank se alistan a comprar firmas comisionistas locales. Retrieved from: http://www.larepublica.co/finanzas/bice-yscotiabank-se-alistan-comprar-firmas-comsionistas-locales_28877.[Accessed on $12 / 02 / 2014]$.

La República (2013). Corpbanca adquiere 51.6\% del capital del Helm Bank Retrieved from: http:/www.larepublica.co/finanzas/corpbanca-adquiere-516del-capital-del-helm-bank_47431.[Accessed on 12/02/2014].

Lagunoff, \& Schreft, S. L. (2001). A model of financial fragility. Journal of Economic Theory, 99(1-2), 220-264

Larrain Vial (2014). Acerca de Larrain Vial. Retrieved from: https://www. larrainvial.com/colombia/sobrenosotros/introduccion.[Accessed $09 / 02 / 2014]$.

Levy, P. I. (1997). A political-economic analysis of free-trade agreements. The American Economic Review, 506-519.

London Stock Exchange (2007). Press Release. Retrieved from http:// www.londonstockexchange.com/about-the-exchange/media-relations/pressreleases/2007/borsaitalianaandlondonstockexchangegrouptomerge.htm. [Accessed on 09/02/2014].

McAndrews, J., \& Stefanadis, C. (2002). The consolidation of European stock exchanges. Current Issues in Economics and Finance, 8(6).

MILA Mercado Integrado Latinoamericano (2010). Integración del mercado de renta variable, Chile. Colombia, Perú. Retrieved from: http://jungleboxsolutions.com/mila/files/publicaciones/6presentacionmjr-asobancaria-congreso-derecho-financiero-28oct10.pdf.[Accessed 09/02/2014]. on 
MILA Mercado Integrado Latinoamericano. (2014). Retrieved from: http://www.mercadomila.com/.[Accessed on 01/06/2013].

MinCIT-Ministerio de Comercio, Indutria y Turismo de Colombia. (2014). Acuerdos vigentes. Retrieved from: http://www.tlc.gov.co/publicaciones. php?id=5398. [Accessed on 09/02/2014].

Ministerio de Hacienda y Crédito Público. República de Colombia. (2008). El mercado de valores colombiano. Retrieved from: http://www.irc.gov.co/ irc/es/mercadovalorescolombiano.[Accessed on 20/03/2013].

Mirus, R., \& Rylska, N. (2001). Economic integration: Free trade areas vs. customs unions. Western Centre for Economic Research.

Mobarek, A. (2013). Global stock market integration and the determinants of co-movements: Evidence from developed and emerging countries. Retrieved from: http://www.nasdaqomx.com/digitalAssets/76/76057. globalstockmarketintegrationandthedeterminantsofcomovementsevidence.pdf.[Accessed on 09/11/2013].

Mukhopadhyay, K., Thomassin, P. J., \& Chakraborty, D. (2012). Economic impact of freer trade in Latin America and the Caribbean: A GTAP analysis. Latin American Journal of Economics, 49(2), 147-183.

Newfarmer, R. (2006). Trade, Doha, and development: A window into the issues. Washington, DC: World Bank.

Nielsson, U. (2009). Stock exchange merger and liquidity: The case of Euronext. Journal of Financial Markets, 12(2), 229-267.

OECD. (2014). Benefits of trade liberalization, Regional trade agreements. Retrieved from: http://www.oecd.org/tad/benefitlib/regionaltradeagreements. htm. [Accessed on: 16/02/2014].

Pagano, M., \& Padilla, A. (2005). Gains from stock exchange integration: The Euronext evidence. Centre for Economic Policy Research.

Portafolio (2012). Marca del banco Santander se despide y llega CorpBanca. Retrieved from: http://m.portafolio.co/negocios/marca-del-banco-santander-se-despidey-llega-corpbanca.[Accessed on 12/02/2014].

Portafolio (2013). Corredores Asociados ya es una empresa del Grupo Bolívar. Retrieved from: http://www.portafolio.co/economia/corredores-asociados-yaes-una-empresa-del-grupo-bolivar.[Accessed on 12/02/2014].

Portafolio (2013). Comisionista Asvalores fue adquirida por Global Securities. Retrieved from: http://www.portafolio.co/economia/global-securitiescolombia-compra-asvalores.[Accessed on 09/02/2014].

Portafolio (2013). Comisionistas independientes, sin miedo a las bancarizadas. Retrieved from: http://www.portafolio.co/negocios/comisionistasindependientes-miedo-las-bancarizadas. [Accessed on 12/02/2014]

Portafolio (2014) Matriz del Grupo Skandia vendió negocios de países nórdicos. Retrieved from: http://m.portafolio.co/negocios/matriz-del-grupo-skandiavendio-negocios-paises-nordicos.[12/02/2012]

Raj, S. Dhal, S. (2008). Integration of India's stock market with global and major regional markets. Bank for International Settlements (BIS) Paper 42. Retrieved from: https://www.bis.org/publ/bppdf/bispap42h.pdf.[Accessed on 09/11/2013].

Revista Dinero (2009). Para dónde va Compass. Retrieved from: http://www. dinero.com/Imprimir.aspx?idItem=72446. [Accessed on 12/02/2014].

Revista Dinero (2012). Grupo chileno compra operación del Banco Santander Colombia. Retrieved from: http://m.dinero.com/negocios/articulo/grupochileno-compra-operacion-del-banco-santander-colombia/141408.[Accessed on $11 / 02 / 2014]$.

Revista Semana (2013). Un buen año para la economía. Retrieved from: http://www.semana.com/economia/articulo/balance-de-la-economiacolombiana-en-2013/369104-3. [Accessed on 11/02/2014].

Robertson, R., \& Estevadeordal, A. (2009). Gravity, bilateral agreements, and trade diversion in the Americas. Cuadernos de economía, 46(133), 3-31.

Robinson, J. (2006). Aspects of the Caribbean single market and economy: How integrated are regional stock markets? Journal of Eastern Caribbean Studies, 31(4), $30-54$

Santander Investment Valores Colombia SA Comisionista de Bolsa (2011). Estados financieros por los años terminados el 31 de diciembre de 2011 y 2010 e
Informe del revisor fiscal. Retrieved from: https://www.bancocorpbanca. com.co/portal/formas/1252/Santander\%20Investment\%20Valores\%20Colombia \%20S\%20A\%20\%20(Notas\%202011-2010)DEF.pdf.[Accessed on 12/02/2014].

Sa-Silva J. R., Almeida, C. D. D. \& Guindani, J. F. (2009). Pesquisa documental: pistas teóricas e metodológicas. Revista Brasileira de História e Ciências Sociais. São Leopoldo, 1(1), 1-15.

Schiff, M.W., \& Winters, L.A. (2003). Regional integration and development. World Bank-free PDF.

Schröder, M. (Ed.). (2001). The new capital markets in Central and Eastern Europe. Springer.

Sebastian, E. (2001). Development centre studies. The economics and politics of transition to an open market economy: Colombia. OECD Publishing.

Servivalores (2011). Notas a los estados financieros. Retrieved from http://www.google.com/url?sa=t\&rct=j\&q=servivalores\%20gnb\%20sudameris \%20notas\%20a\%20los\%20estados\%20financieros\&source=web\&cd=2\&cad=rja \&ved=0CC0QFjAB\&url=http\%3A\%2F\%2Fwww.servivalores.gnbsudameris.com. co\%2Fdownload.php\%3Ffile\%3DNotas_Estados_financieros.pdf\&ei=jhf8UpKONI LWkQeK84DwBQ\&usg=AFQjCNHFNFjy2YdJqGge2PKdPNIVhORWOQ\&bvm=bv. 61190604,d.eW0.[Accessed on 12/09/2014].

Skandia, Sala de prensa (2014). Cambian nuestras razones sociales. Retrieved from: http://www.skandia.com.co/site/Default.aspx?tabid=589\&language=enUS. [Accessed on 12/02/2014].

Stoltenberg, C., George, B., Lacey, K. A., \& Cuthbert, M. (2011). The past decade of regulatory change in the U. and EU aapital market regimes: An evolution from national interests toward international harmonization with emerging G-20 leadership. Berkeley Journal of International Law, 29(2), 577-648.

Superintendencia Financiera de Colombia (2012). Nuevos retos del sector financiero colombiano. Retrieved from: http://www.asobancaria. com/portal/page/portal/Eventos/eventos/congreso_derecho_financiero_2012/ Tab5/Gerardo\%20Hernandez.pdf.[Accessed on 09/02/2014].

Superintendencia Financiera de Colombia, SIMEV (2014). Registro Nacional de Agentes del Mercado de Valores RNAMV. Retrieved from: https:// www.superfinanciera.gov.co/jsp/loader.jsf?IServicio=Publicaciones\&lTipo= publicaciones\&1Funcion=loadContenidoPublicacion\&id=80180. [Accessed on $12 / 09 / 2014]$.

Tambi, M.K. (2005). Integration of financial markets (No. 0504014). EconWPA.

Ultrabursátiles (2013). Notas a los estados financieros consolidados 2012 y 2011. Retrieved from: https://www.ultrabursatiles.co/sites/default/files/ informacion_financiera/pdf/Estados\%20Financieros\%20 Consolidados\%202012.pdf.[Accessed on 12/02/2014].

Valores Bancolombia (2011). Notas a los estados financieros 31 de diciembre 2011 y 2010. Retrieved from: http://www.valoresbancolombia.com/cs/ Satellite?blobcol=urldata\&blobheadername $1=$ content-type \& blobheadername2=Content-Disposition\&blobheadername3=MDT-Type\& blobheadervalue 1=application\%2Fpdf\&blobheadervalue2=inline\%3B+filename \%3Dmyfile\&blobheadervalue3=abinary\%253B\%2Bcharset\%253DUTF$8 \&$ blobkey=id\&blobtable=MungoBlobs\&blobwhere $=1266523545902 \&$ ssbinary $=$ true.[Accessed on 12/02/2014].

Varadi, V. K., \& Boppana, N. (2009). Are stock exchanges integrated in the world? A critical analysis. Journal of Applied Research in Finance (JARF), 2(2), 244-257.

Wakasugi, R., Todo, Y., Sato, H., Nishioka, S., Matsuura, T., Ito, B., \& Tanaka, A. (2008). The internationalization of Japanese firms: New findings based on firm-level data. The Research Institute of Economy, Trade and Industry, RIETI Research Digest, (01).

Whalley, J. (1998). Why do countries seek regional trade agreements? In The regionalization of the world economy. University of Chicago Press.

WTO - World Trade Organization. (2014). Regional trade agreements information system (RTA-IS) RTA Database, List of all RTAs. Retrieved from: http://rtais.wto.org/UI/PublicAllRTAList.aspx.[Accessed on 16/02/2014].

Yin, Robert K. (1994). Case study research: Design and methods. Sage Publications.

Young, A. (1991). Learning by doing and the dynamic effects of international trade. The Quarterly Journal of Economics, 106(2), 369-405. 